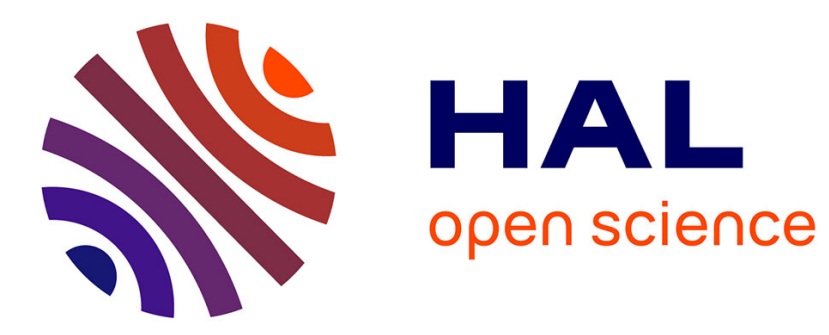

\title{
Dye sensitization of ceramic semiconducting electrodes for photoelectrochemical conversion
}

\author{
N. Alonso V., M. Beley, Philippe Chartier, V. Ern
}

\section{To cite this version:}

N. Alonso V., M. Beley, Philippe Chartier, V. Ern. Dye sensitization of ceramic semiconducting electrodes for photoelectrochemical conversion. Revue de Physique Appliquée, 1981, 16 (1), pp.5-10. 10.1051/rphysap:019810016010500 . jpa-00244894

\section{HAL Id: jpa-00244894 https://hal.science/jpa-00244894}

Submitted on 1 Jan 1981

HAL is a multi-disciplinary open access archive for the deposit and dissemination of scientific research documents, whether they are published or not. The documents may come from teaching and research institutions in France or abroad, or from public or private research centers.
L'archive ouverte pluridisciplinaire HAL, est destinée au dépôt et à la diffusion de documents scientifiques de niveau recherche, publiés ou non, émanant des établissements d'enseignement et de recherche français ou étrangers, des laboratoires publics ou privés. 


\title{
Dye sensitization of ceramic semiconducting electrodes for photoelectrochemical conversion
}

\author{
N. Alonso V., M. Beley, P. Chartier \\ Laboratoire d'Electrochimie et de Chimie Physique du Corps Solide, \\ Université Louis-Pasteur, 4, rue Blaise-Pascal, 67000 Strasbourg, France \\ and V. Ern \\ Institut de Physique (*), Université Louis-Pasteur, 5, rue de l’Université, 67000 Strasbourg, France
}

(Reçu le 28 juillet 1980, accepté le 13 octobre 1980)

\begin{abstract}
Résumé. - Des électrodes céramiques semi-conductrices de $\mathrm{ZnO}$ ont été sensibilisées par des colorants Rhodamine B et complexes de Ru (II). Ainsi, la photoréponse des cellules photoélectrochimiques, stabilisées en utilisant l'hydroquinone comme régénérateur, peut être étendue au domaine visible (400-600 $\mathrm{nm}$ ). Une tension en circuit ouvert de $0,4 \mathrm{eV}$ et des courants de court-circuit jusqu'à $0,2 \mathrm{~mA}$ peuvent être obtenus en utilisant des photons dont $h v<E_{\text {gap }}$ du semiconducteur.

Abstract. - Semiconducting $\mathrm{ZnO}$ ceramic electrodes have been sensitized by Rhodamine B and $\mathrm{Ru}$ (II) complex dyes. The photoresponse of the stable electrochemical cells can thus be extended into the visible region $(400-600 \mathrm{~nm})$ using hydroquinone as supersensitizer. Open circuit voltage of $0.4 \mathrm{~V}$ and short circuit currents up to $0.2 \mathrm{~mA}$ can be obtained with photons of $h v<E_{\text {gap }}$ of semiconductor.
\end{abstract}

1. Introduction. - Photovoltaic conversion of solar energy with solid state p-n or metalsemiconductor Schottky barrier junctions has found already extensive application in low power installations. Efficiencies near the theoretical values have been obtained, but the cost of fabrication of reasonably good junctions remains high, and considerable research and development effort, notably with amorphous materials is still actively pursued to bring down the cost of the device. Recently several laboratories throughout the world have started parallel research on the feasibility of using electrochemical cells. An electrochemical cell consists simply of a p- or n-type semiconductor, an electrolyte, and a counter-electrode to collect the charge carriers. In such a system the cost of fabrication of the junction is eliminated, since the simple immersion of the semiconductor in the electrolyte creates the depletion layer which is necessary to obtain the

(*) This work was supported by grant PIRDES ATP 3866 of the Centre National de la Recherche Scientifique in conjunction with the Laboratoire de Spectroscopie and the Laboratoire d'Applications Electroniques. photovoltaic effect. Moreover, with transparent electrolytes, reflection and absorption losses due to the metallic contact on the solid state device are eliminated. Besides, scientific interest is accrued by the fact that, under suitable conditions, it could also work as a solar energy-assisted photochemical or photoelectrochemical device which splits water for the purpose of generating chemical energy in the form of a storable fuel.

An obvious problem with photoelectrochemical cells is their long range stability since, in general, and more like so with low band-gap materials, anodic dissolution of the electrode competes with the redox reaction, and a corrosion of the electrode takes place. The stability problem has been object of intensive studies and several stable electrode-redox couples have been claimed. Recent reviews can be found in references $[1,2,3]$. Other approach is the use of stable high band-gap semiconductor oxide electrodes, e.g. $E_{\text {gap }}>3 \mathrm{eV}$, like $\mathrm{TiO}_{2}, \mathrm{ZnO}, \mathrm{SrTiO}_{3}, \mathrm{SnO}_{2}$, and to extend the useful spectral response range down into the visible region by sensitization with organic dye molecules. Photosensitization with organic dyes has been studied for some time in conjunction with photographic and electrographic processes. More recently, 


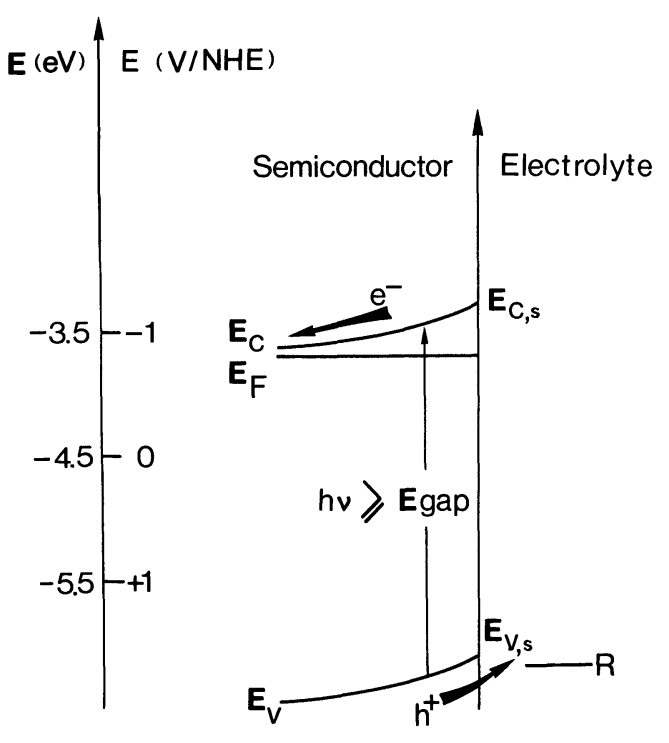

(a)

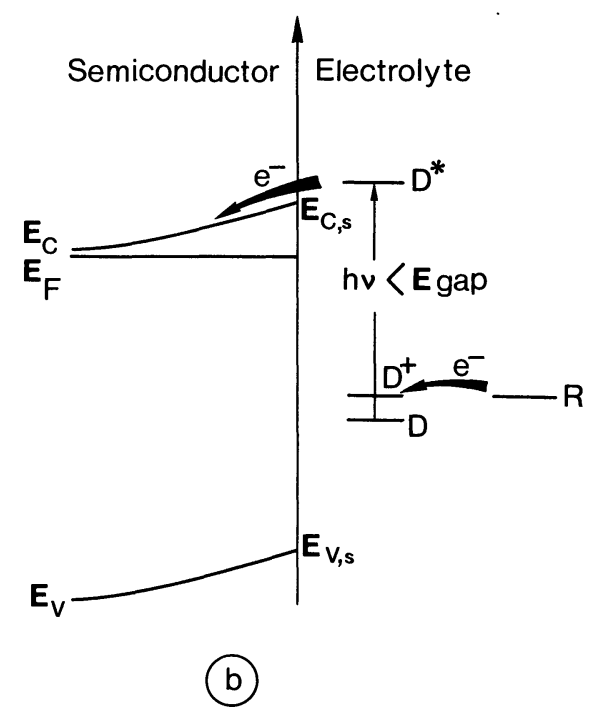

Fig. 1. - Schematic energy diagram of the photovoltaic effect for a n-type semiconductor in an electrolyte : a) without sensitization, $b$ ) sensitized with an organic molecule having energy levels $\mathrm{D}, \mathrm{D}^{*}, \mathrm{D}^{+}$corresponding to the ground, excited (triplet or singlet) and oxidized states. The excitation $\mathrm{D} \rightarrow \mathrm{D}^{*}$ is obtained with photons with $h v<E_{\mathrm{gap}}$ of semiconductor. The level $\mathrm{R}$ symbolizes the energy of a regenerating species in the electrolyte which assures reduction of the molecule back to its ground state. The correspondance of energy scales as customarily used in solid state physics (zero at vacuum level) and in electrochemistry, where the normal hydrogen electrode (NHE) is used as reference is shown on the left. In the present work saturated calomel electrode (SCE) is used as reference, the scale transformation being $E(\mathrm{~V} / \mathrm{SCE})=E(\mathrm{~V} / \mathrm{NHE})-0.24 \mathrm{~V}$.

an extensive research program has been started all over the world to investigate, both from a theoretical and a practical point of views, the sensitization by organic dyes of the interface of semiconductorelectrolyte systems as potential candidates for solar energy conversion by stable, wet photoelectrochemical cells. A schematic energy diagram of the principle of operation is shown in figure 1. A review up to 1976 has been given by Gerischer and Willig [4]. Later work can be found in references [5-21]. Most of the work has been done on single crystals, with exception of $\mathrm{SnO}_{2}$ films [18-20] and $\mathrm{ZnO}[6,7]$ ceramic electrodes. With single crystals the cost of the cell would not likely be competitive with a solid state device, so that the most promising aspect of photoelectrochemical conversion is that using polycrystalline semiconducting electrodes, e.g. thin films or ceramics. Sensitization of $\mathrm{ZnO}$ ceramic electrodes has been performed $[6,7]$ by using rose bengal dye which requires the $\mathrm{I}_{3}^{-} / \mathrm{I}^{-}$redox couple as regenerator. Unfortunately, such an electrolyte absorbs in the visible region. It is interesting thus to investigate others systems in which dyes in conjunction with a transparent electrolyte can be used.

Organometallic dyes such as $\mathrm{Ru}(\text { bipy })_{3}^{2+}$, i.e. tris ( $2,2^{\prime}$ bipyridine) ruthenium (II), and related complexes have been increasingly attracting attention since the first report [22] of their ability to induce electron transfer reaction of the excited state, and the work by Creutz and Sutin [23] who pointed out the possibility of decomposition of water induced by visible light. Recent research development in this field can be found in references [24] to [26]. The ground state complex absorbs visible light to form a d to $\pi^{*}$ charge transfer excited state which is relatively long lived (lifetime $0.6 \mu$ s in water) [22] as compared to conventional organic dyes (lifetime about $10^{-9} \mathrm{~s}$ ). It seems that this excited state is a triplet charge transfer state. $\mathrm{TiO}_{2}$ single crystals have been already sensitized with the Ru (bipy) $)_{3}^{2+}$ dye by Clark and Sutin [13] and later by Hammet et al. [14]. Also, sensitization has been obtained on the same electrode by chemical attachment of the dye on the crystal [12]. Chemically stable electrode was then obtained, but the photocurrent excitation spectrum did not show the characteristic absorption peak of the dye at $\sim 450 \mathrm{~nm}$. Memming and coworkers [18-20] have sensitized $\mathrm{SnO}_{2}$ films, one of their techniques [19] consisted of applying monolayers by the Langmuir-Bloogett method of the $\mathrm{Ru}$ (II) complexes of the type :

$$
\left[\left(2,2^{\prime} \text { (bipy) }\right)_{2} \mathrm{Ru}(\mathrm{II})\left(2,2^{\prime} \text { (bipy) } 4,4^{\prime} \mathrm{R}_{2}\right)\right]^{2+}\left(\mathrm{ClO}_{4}^{-}\right)_{2}
$$

where :

$$
\mathrm{R}=-\underset{\mathrm{O}}{\mathrm{C}}-\mathrm{O}-\mathrm{C}_{18} \mathrm{H}_{37} \text { (distearyl) : type I }
$$

or

$$
\mathrm{R}=-\mathrm{C}_{19} \mathrm{H}_{39} \text { (dinonadecyl) : type II . }
$$

Also, recently, Mackor and Schonmann [15] have reported sensitization of pure and doped $\mathrm{SrTiO}_{3}$ 
single crystals with the type II dinonadecyl complex of $\mathrm{Ru}$ (II) although the, simpler, complex $\mathrm{Ru}$ (bipy) ${ }_{3}^{2+}$ seems not sensitize $\mathrm{SrTiO}_{3}$ single crystals [13].

In this work we wish to report studies of sensitization of semiconducting $\mathrm{ZnO}$ ceramic electrodes with $\mathrm{Ru}$ (II) dye molecules of type II. As this dye absorbs at $\sim 450 \mathrm{~nm}$, we have also investigated the feasibility of extending the spectral response towards longer wavelengths by using a mixture of $\mathrm{Ru}$ (II) and Rhodamine $\mathrm{B}(\mathrm{RhB})$ dyes adsorbed on the electrode.

2. Experimental. - Ceramics of $\mathrm{ZnO}(1.2 \mathrm{~cm}$ in diameter) were prepared from commercial high grade zinc oxide powder (Merck pro analysi) by sintering in two steps. The pellets were first moulded by compression (10 ton.) before firing in air at $1000^{\circ} \mathrm{C}$ for $3 \mathrm{~h}$, and quenched. It were then ground into fine powder, pressed again into disks and heated at $1300^{\circ} \mathrm{C}$ for $3 \mathrm{~h}$, and quenched. The samples obtained by this method were semiconducting with a resistivity $\sim 10^{3} \Omega . \mathrm{cm}$ at room temperature. Contacts on the back surface were made by attaching a fine copper wire with silver paste (Degussa 2000) which makes an ohmic contact with the ceramic. The samples were then mounted in glass tubes and moulded with an epoxy resin. Prior to use, the front surface of the electrode was etched for $3 \mathrm{~min}$. in $5 \mathrm{~N} \mathrm{HCl}$ solution which attacked the surface exposing grain (typically $20 \mu$ ) boundaries as observed by microscopy.

All electrolytes were made with distilled water. The base electrolyte was $1.5 \mathrm{M} \mathrm{KCl}$ with $5 \times 10^{-3} \mathrm{M}$ hydroquinone $\left(\mathrm{H}_{2} \mathrm{Q}\right)$ which served as dye reducing agent. Before each experiment the electrolyte was purged with nitrogen. Prior to the application of the dye each electrode was tested for a correct $I-V$ Schottky barrier rectifying characteristics. The electrodes were coated with the dye as follows. The electrode was immersed in a $10^{-3} \mathrm{M}$ acetonitrile solution of the Ru (II) complex, type II, for $30 \mathrm{~min}$, then washed with distilled water in which the dye is insoluble, and dried. On several electrodes prepared in this way $\mathrm{RhB}$ was deposited by dipping for few seconds in $10^{-3} \mathrm{M}$ Rhodamine $\mathrm{B}$ in acetonitrile solution. After drying the electrode were washed with distilled water to eliminate excess $\mathrm{RhB}$ deposited on the sample. Tests to sensitize simultaneously with both dyes by immersion in a $10^{-3} \mathrm{M} \mathrm{Ru}$ (II) complex $+10^{-3} \mathrm{M} \mathrm{RhB}$ acetonitrile solution gave only electrodes sensitized by the $\mathrm{Ru}$ (II) complex indicating preferential adsorption of the organometallic dye on the $\mathrm{ZnO}$ ceramic surface.

The experimental setup is shown in figure 2. The semiconductor electrode and a platinum wire counterelectrode were placed in close proximity to each other. A saturated calomel reference electrode (SCE) was used to control the working electrode potential. A $150 \mathrm{~W}$ xenon arc lamp served as a light source, which was passed through a water filter followed by a monochromator (Jobin Yvon H25). In some experiments the monochromator was replaced by a C.S.

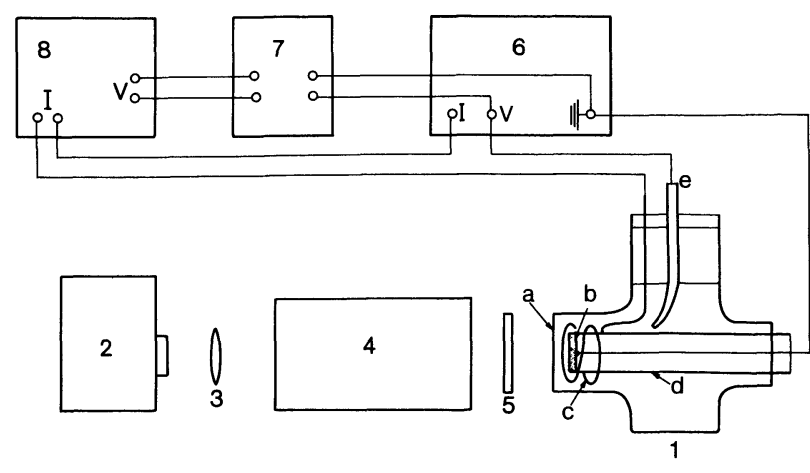

Fig. 2. - Experimental setup : 1 Cell ( $a$, flat window ; $b$, semiconducting electrode; $c$, platinum counter-electrode; $d$, glass tube; $e$, saturated calomel electrode (SCE)); 2 a $150 \mathrm{~W}$ XBO xenon arc lamp ; 3 Lens ; 4 Monochromator ; 5 Filter ; 6 Potentiostat ; 7 Digital voltmeter with analog output; $8 X Y$ recorder.

3-72 Corning filter with which a broad band excitation in the visible range $(400-700 \mathrm{~nm})$ is obtained. The potentiostatic measurements were done in a standard manner with a potentiostat (Tacussel type P.R.T. 2000) with which the current-voltage characteristics were recorded on a $X-Y$ recorder. The exciting light intensity was determined by means of a thermopile (KippZonen) together with a microvoltmeter. An electrolyte layer with thickness corresponding to the experimental distance between the cell window and the photoelectrode was inserted into the light beam to correct for any absorbance or reflection so that the actual intensity falling on the sample could be estimated. All data were normalized to a constant, independent of $\lambda$, incident light power.

3. Results and discussion. - In the dark the rest potential of the $\mathrm{ZnO}$ electrode in the $1.5 \mathrm{M} \mathrm{KCl}$ electrolyte $(\mathrm{pH} \simeq 6.5)$ was reproducibly found in the $\sim+50 \mathrm{mV} / \mathrm{SCE}$ region. The value was the same both with the uncoated and with the dye-covered electrodes. Furthermore, this dark rest potential is unsensitive to the presence of hydroquinone $\left(\mathrm{H}_{2} \mathrm{Q}\right)$ or even of quinhydrone $\left(\mathrm{QH}_{2} \mathrm{Q}\right)$ in the electrolyte, that is, the semiconductor electrode doesn't pick up the redox potential of the $\mathrm{Q} / \mathrm{H}_{2} \mathrm{Q}$ couple. The dark current was found to be sensitive to the presence of $\mathrm{O}_{2}$ in the electrolyte. It increases by a factor of 2-3 when $\mathrm{O}_{2}$ is bubbled through a previously outgassed solution. In the photoexcited experiments the platinum counter-electrode potential was typically $+0.140 \mathrm{~V} /$ SCE. This potential is not well thermodynamically defined because of the absence of quinone in the hydroquinone containing solution. Thus, all experiments were performed under potentiostatic conditions ( $v s$. SCE). The solutions were always outgassed and photocurrent action spectra obtained with the $\mathrm{ZnO}$ electrode polarized at $+50 \mathrm{mV} / \mathrm{SCE}$ so that the dark current could be considered as negligible in the experiment.

Figure 3 shows the photocurrent response as a function of wavelength for a ceramic $\mathrm{ZnO}$ electrode sensitized with the Ru(II), type II complex. For 


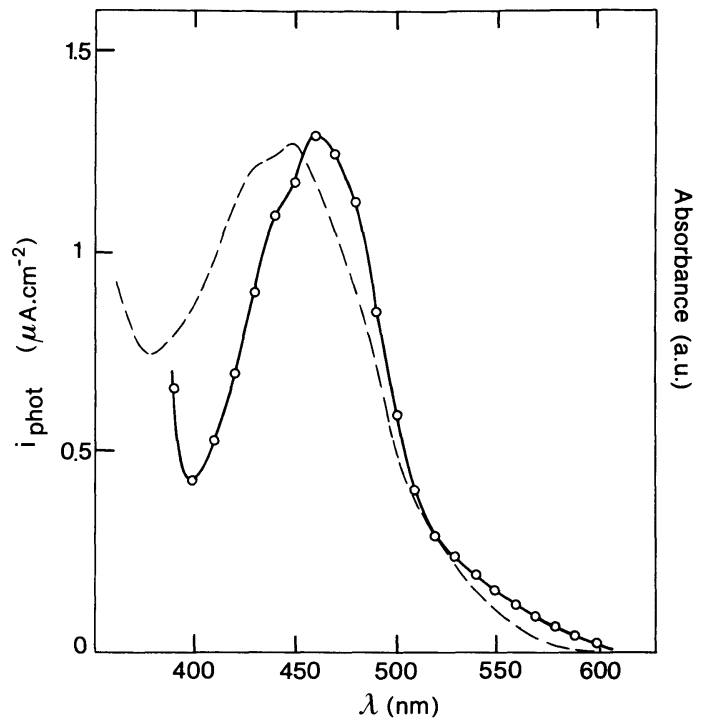

Fig. 3. - Photocurrent action spectrum of a $\mathrm{ZnO}$ ceramic electrode sensitized with the dinonadecyl Ru (II) complex dye (type II shown in text). The electrode is held at $+50 \mathrm{mV} / \mathrm{SCE}$ and excited at a constant light power of $0.28 \mathrm{~mW} . \mathrm{cm}^{-2}$ throughout the spectrum. The dashed curve shows for comparison the absorption spectrum (in a.u.) of a $10^{-3} \mathrm{M}$ acetonitrile solution of the dye.

comparison, the absorption profile (a.u.) of the dye in a $10^{-3} \mathrm{M}$ acetonitrile solution is also shown. Both curves show similar, well defined, structure but the photocurrent peak is shifted towards the longer wavelengths. Such red shift is usually observed in semiconductor sensitization responses and has been attributed by Gerischer [27] to a stronger polarization interaction of the molecular excited state with the semiconductor as compared to that of the ground state. This observation agrees with the results on $\mathrm{SnO}_{2}$ films by Memming et al. [19], but contrasts with the results of Anderson et al. [12] who obtained a featureless photocurrent action spectrum with derivatives of $\mathrm{Ru}$ (bipy) ${ }_{3}^{2+}$ chemically attached to $\mathrm{TiO}_{2}$ crystals. Figure 4 shows the photocurrent response of the same electrode which has been subsequently sensitized with Rhodamine B dye as described previously. The photoresponse extends now into the yellow region showing the characteristic peak of RhB sensitization at $\sim 560 \mathrm{~nm}$. The insert gives, for comparison, the response of a ceramic $\mathrm{ZnO}$ electrode coated just with RhB. This RhB excitation spectrum is analogous to that observed by Gerischer et al. for $\mathrm{ZnO}$ single crystals [4]. The overall maximum monochromatic quantum efficiency $(\simeq 1.5 \%)$ is obtained at the $\mathrm{Ru}^{\prime}$ (II) complex peak and is the same whether or not the electrode has been also sensitized with $\mathrm{RhB}$. This seems to indicate that partial coverage by $\mathrm{Ru}$ (II) complex dye takes place at selective sites of the ceramic surface and that the RhB molecules adsorb at different sites. This may explain the relatively small quantum efficiency although other effects like a high charge carrier-recombination rate at the $\mathrm{ZnO}$-electrolyte interface or a small dye-semiconductor charge transfer rate, as compared to the direct to the ground state,

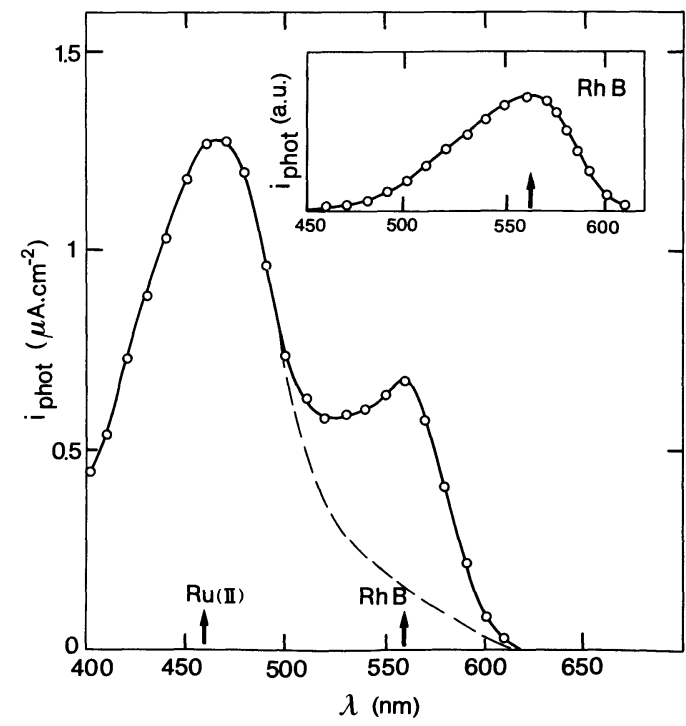

Fig. 4. - Photocurrent action spectrum performed under the same conditions as in figure 3 but with the $\mathrm{ZnO}$ electrode subsequently sensitized with Rhodamine B dye as described in text. The dashed extension of the $\mathrm{Ru}$ (II) complex peak corresponds to data as obtained prior to Rhodamine B sensitization (Fig. 3). The insert illustrates the photoresponse of a $\mathrm{ZnO}$ ceramic electrode when sensitized just with the Rhodamine B dye.

fluorescent or non-radiative, deactivation rate of the molecular excited state, cannot be yet ruled out.

An important parameter, useful to compare the performance of the ceramic semiconductor with that of a single crystal, is the flat band potential $E_{\mathrm{fb}}$ which gives a measure of the band bending obtained in the depletion layer at the semiconductor surface in contact with the electrolyte. As pointed out by Gerischer et al. [4] the flat band potential can be obtained from the $I-V$ characteristics of the sensitized cell, since the potential (e.g. vs. SCE) for the onset of the photocurrent is a mesure of $E_{\mathrm{fb}}$ because, for dyes whose excited state lies above the surface edge of the valence band, as shown in figure 1, injected electron flow will start with the onset of the bending of the band. Figure 5

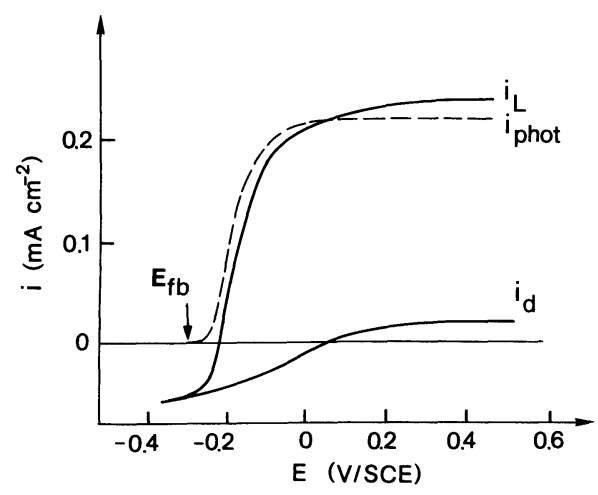

Fig. 5. - Extended current-voltage characteristics of a doubly sensitized $\mathrm{ZnO}$ ceramic in the dark (curve $i_{\mathrm{d}}$ ) and under broad band $(400-700 \mathrm{~nm})$ excitation in the absorption region of the dyes (curve $i_{\mathrm{L}}$ ). Subtraction of the dark current yields the characteristics $i_{\text {phot }}$ (dashed curve). The onset of the photocurrent occurs at a flat band potential of $E_{\mathrm{fb}}=-0.3 \mathrm{~V} / \mathrm{SCE}$. 
shows the $I-V$ characteristics of a doubly sensitized $\mathrm{ZnO}$ electrode. The dark current $\left(i_{\mathrm{d}}\right)$ is shown together with the characteristics $\left(i_{\mathrm{L}}\right)$ obtained with a broad band (400-700 nm) visible light excitation of the dyes. After subtraction of the dark current the characteristic $i_{\text {phot }}$ (dashed curve) is obtained with an onset at the flat band potential $E_{\mathrm{fb}} \simeq-0.3 \mathrm{~V} / \mathrm{SCE}$. This value is close to the value predicted for single crystals of $\mathrm{ZnO}$ with the law [28] $E_{\mathrm{fb}}=E_{\mathrm{fb}}^{0}-0.060 \mathrm{pH}$ and using the value of $E_{\mathrm{fb}}=-0.38 \mathrm{~V} / \mathrm{SCE}$ given by Dewald [29] at $\mathrm{pH}$ 8.5. It seems thus that the photovoltaic effect observed here occurs mainly at grains whose surfaces have electrochemical properties similar to that of single crystals of $\mathrm{ZnO}$.

It is worthwhile to analyse the role of hydroquinone $\left(\mathrm{H}_{2} \mathrm{Q}\right)$ as supersensitizer of the $\mathrm{Ru}$ (II) complex dye in the regenerative cell. It has been shown by several authors $[12-15,18,19]$ that the product of oxidation of the excited ${ }^{*} \mathrm{Ru}$ (II) state, that is, the corresponding $\mathrm{Ru}$ (III) oxidized form can oxidize $\mathrm{H}_{2} \mathrm{O}$ molecules without the need of any other reducible species in the electrolyte. This is due to the fact that the respective standard redox potentials for the different $\mathrm{Ru}$ (II) complexes lie in the ranges $E_{\mathbf{R u}(\mathrm{III}) / \mathbf{R u}(\mathrm{II})}^{0}=0.85$ to 1.25 and $\mathrm{E}_{\mathrm{Ru}(\mathrm{IIII}) / \mathrm{Ru} \text { (II) }}^{0}=-1.25$ to $-1.01 \mathrm{~V} / \mathrm{SCE}$ [30]. Assuming the redox potentials of the dye used here to lie in the same region, the following reaction mechanisms can be considered to take place :

$$
\begin{aligned}
& \mathrm{Ru}(\mathrm{II})+h v \rightarrow{ }^{*} \mathrm{Ru}(\mathrm{II}) \\
& \left.* \mathrm{Ru} \text { (II) } \rightarrow \mathrm{Ru}(\mathrm{III})+\mathrm{e}^{-} \text {(in } \mathrm{ZnO}\right) \\
& * \mathrm{Ru}(\mathrm{II}) \rightarrow \mathrm{Ru}(\mathrm{II})+h v^{\prime} \text { (fluorescence) } \\
& \mathrm{Ru}\left(\text { III) }+\frac{1}{2} \mathrm{H}_{2} \mathrm{O} \rightarrow \mathrm{Ru} \text { (II) }+\frac{1}{4} \mathrm{O}_{2}+\mathrm{H}^{+}\right. \\
& \mathrm{Ru}(\mathrm{III})+\frac{1}{2} \mathrm{H}_{2} \mathrm{Q} \rightarrow \mathrm{Ru} \text { (II) }+\frac{1}{2} \mathrm{Q}^{+} \mathrm{H}^{+} .
\end{aligned}
$$

Process $(a)$ is the excitation of the dye by the external photon flux, $(b)$ and $(c)$ are competitive processes for the decay of the excited state either by an electron transfer to the semiconductor or by radiative decay to the molecular ground state, respectively. Processes $(d)$ and $(e)$ are the regenerative processes leading to the reduction of the oxidized state left after process $(b)$. Both processes $(d)$ and $(e)$ are energetically possible since at $\mathrm{pH} 6.5$ the redox potentials

$$
E_{\mathrm{Q} / \mathrm{H}_{2} \mathrm{Q}}^{0}=0.07 \mathrm{~V} / \mathrm{SCE}
$$

and $E_{\mathrm{O}_{2} / \mathrm{H}_{2} \mathrm{O}}^{0}=0.60 \mathrm{~V} / \mathrm{SCE}$ are both smaller than $E_{\mathrm{Ru}(\mathrm{III}) / \mathrm{Ru}(\mathrm{II})}^{0}$ and should compete with each other. The fact that process $(d)$ is also operative is verified by the observation that without $\mathrm{H}_{2} \mathrm{Q}$ in the electrolyte a small photocurrent can be sustained though the cell with a slow evolution of oxygen gas at the sensitized semiconductor surface. Supersensitization by a factor of about 4 when hydroquinone is present in the system indicates that $\mathrm{H}_{2} \mathrm{Q}$ is oxidized at a faster rate than $\mathrm{H}_{2} \mathrm{O}$ and process $(e)$ is predominant.

The $I-V$ characteristics of a doubly sensitized cell under a broad $(400-700 \mathrm{~nm})$ visible light excitation in the dyes absorption region is shown in figure 6.

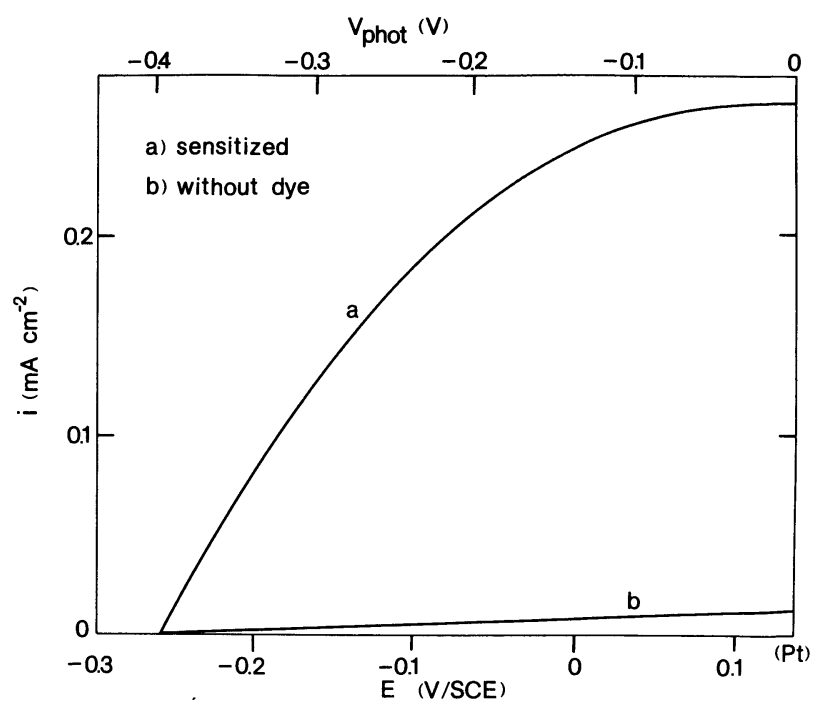

Fig. 6. - Fourth quadrant (positive power) current-voltage characteristics of the doubly sensitized $\mathrm{ZnO}$ ceramic electrode cell under $0.4 \mathrm{~W} . \mathrm{cm}^{-2}$ broad band $(400-700 \mathrm{~nm})$ excitation in the absorption region of the dyes and under potentiostatic SCE conditions. The open circuit voltage of the cell, with respect to the metallic $(\mathrm{Pt})$ electrode, is $0.4 \mathrm{~V}$ as indicated by the upper scale. The response under the same conditions of a non sensitized $\mathrm{ZnO}$ ceramic (curve $b$ ) is also shown.

For comparison the response of the same electrode but without dye coating (curve $b$ ) is also shown. Under potentiostatic conditions and with a power of incident light of $\sim 0.4 \mathrm{~W} . \mathrm{cm}^{-2}$ the maximum short circuit current densities obtained so far lie in the $0.22-0.24 \mathrm{~mA} . \mathrm{cm}^{-2}$ range. The open circuit voltage of the cell is $V_{\mathrm{OC}}=0.4 \mathrm{~V}$ as shown by the upper scale of figure 6 , referred to the platinum counter-electrode.

4. Conclusion. - It is shown that stable photoelectrochemical cells with broad response in the visible region can be obtained by sensitizing with dye mixtures, including an organometallic dye, ceramic semiconducting oxide electrodes and using transparent electrolytes containing hydroquinone as a supersensitizer. Although it is premature to speculate on any future technological application of such device, it is worthwhile to emphasize that cheap, large scale, production of ceramic oxides is already a well known art in electro-acoustic transducer technology. Moreover, ceramics have the advantage of increasing the effective electrode area and a better use of diffuse light. Clearly, many problems remain to be solved, namely the reduction of the series resistances without degration of charge carrier recombination rates at the surface, improvement of dye adsorption techniques, and systematic studies of dye-electrode systems in which the radiative and non-radiative decay rates of the molecular excited state become negligible as compared to the rate of oxidation of the dye by the electron transfer to the electrode. Such work retains 
also a purely scientific interest since it is expected that many ceramic electrodes will behave in a not much very different way from single crystals and the electrochemistry as well as the mechanisms responsible for the deactivation of excited states of organic molecules in the proximity of a semiconducting surface could be studied in systems where single crystals are difficult to obtain.

Acknowledgements. - We are grateful to Dr. J. P. Sauvage of the Laboratoire de Chimie Physique Organique for supplying the dinonadecyl Ru (II) dye.

\section{References}

[1] Memming, R., Electrochim. Acta 25 (1980) 77.

Heller, A. and Miller, B., ibid. 25 (1980) 29.

[2] Horowitz, G. and Bourrasse, A., Revue Phys. Appl. 15 (1980) 463.

[3] Clechet, P., Martelet, C., Martin, J. R. and Olier, R., Actual. Chim. No 9 (1978) 17.

[4] Gerischer, H. and Willig, F., Topics in Current Chemistry, (Springer Verlag, Berlin-Heidelberg) 61 (1976) 31.

[5] Hauffe, K. and Bode, U., Faraday Discuss. Chem. Soc. 58 (1974) 281.

[6] Tsubomura, H., Matsumura, M., Nomura, Y. and AmaMIYA, T., Nature 261 (1976) 402.

[7] Matsumura, M., Nomura, Y., Tsubomura, H., Bull. Chem. Soc. Japan 50 (1977) 2533.

[8] Danzmann, H. J. and Hauffe, K., Ber. Bunsenges. Phys. Chem. 79 (1975) 438.

[9] Watanabe, T., Nakao, M., Fujishima, A. and Honda, K., Ber. Bunsenges. Phys. Chem. 84 (1980) 74

[10] Danzmann, H. J., Hauffe, K. and Szabó, Z. G., Z. Phys. Chem. N.F. 104 (1977) 95.

[11] Yamase, T., Gerischer, H., Lübke, M. and Pettinger, B., Ber. Bunsenges. Phys. Chem. 83 (1979) 658

[12] Anderson, S., Constable, E. C., Dare-Edwards, M. P., Goodenough, J. B., Hammet, A., Seddon, K. R. and Wright, R. D., Nature 280 (1979) 571.

[13] Clark, W. D. K. and Sutin, N., J. Am. Chem. Soc. 99 (1977) 4676.

[14] Hammet, A., Dare-Edwards, M. P., Wright, R. D., SedDON, K. R. and Goodenough, J. B., J. Phys. Chem. 83 (1979) 3280.
[15] Mackor, A., Schoonmann, J., Rec., J. R. Netherlands Chem. Soc. 99 (1980) 71

[16] Fujishima, A., Watanabe, T., Tatsuoki, O. and Honda, K. Chem. Lett. Japan (1975) 13.

[17] Fujishima, A., Iwase, T., Watanabe, T. and Honda, K., J. Am. Chem. Soc. 97 (1975) 4133.

[18] Memming, R., Schröppel, F. and Bringmann, U., J. Electroanal. Chem. 100 (1979) 307.

[19] Memming, R., Schröppel, F., Chem. Phys. Lett. 62 (1979) 207.

[20] Memming, R., Faraday Discuss. Chem. Soc. 58 (1974) 261.

[21] Arden, W., Fromherz, P., Ber. Bunsenges. Phys. Chem. 82 (1978) 868.

[22] Gafney, H. D., Adamson, A. W., J. Am. Chem. Soc. 94 (1972) 8238.

[23] Creutz, C., Sutin, N., Proc. Natl. Acad. Sci. U.S.A. 72 (1975) 2858.

[24] Sutin, N., J. Photochemistry 10 (1979) 19.

[25] Kirch, M., Lehn, J. M., Sauvage, J. P., Helv. Chim. Acto 62 (1979) 1345

[26] Moradpour, A., Actual. Chim. No 2 (1980) 7 .

[27] Gerischer, H., Faraday Discuss. Chem. Soc. 58 (1974) 219.

[28] Lohmann, F., Ber. Bunsenges. Phys. Chem. 70 (1966) 428.

[29] Dewald, J. F., Bell Syst. Tech. J. 39 (1960) 615.

[30] Sutin, N., Creutz, C., in Inorganic and Organometallic Photochemistry, Adv. in Chemistry Series 168, edited by Wrighton, M. S., (Am. Chem. Society Publications, Washington, D.C.) 1978 , p. 1 . 